\title{
OpenAI R@RGU
}

\section{The Open Access I nstitutional Repository at Robert Gordon University}

\author{
http://openair.rgu.ac.uk
}

This is an author produced version of a paper published in

Building Services Engineering Research and Technology (ISSN 01436244)

This version may not include final proof corrections and does not include published layout or pagination.

\section{Citation Details}

Citation for the version of the work held in 'OpenAI R@RGU':

TAYLOR, B. J. and IMBABI, M. S., 1999. Dynamic insulation in multistorey buildings. Available from OpenAI R@RGU. [online]. Available from: http:/ / openair.rgu.ac.uk

\section{Citation for the publisher's version:}

TAYLOR, B. J. and IMBABI, M. S., 1999. Dynamic insulation in multistorey buildings. Building Services Engineering Research and Technology, 20(4), pp. 179-184.

\section{Copyright}

Items in 'OpenAIR@RGU', Robert Gordon University Open Access Institutional Repository, are protected by copyright and intellectual property law. If you believe that any material held in 'OpenAIR@RGU' infringes copyright, please contact openair-help@rgu.ac.uk with details. The item will be removed from the repository while the claim is investigated. 


\section{DYNAMI C I NSULATI ON I N MULTI -STOREY BUI LDI NGS}

\section{B J Taylor $^{\mathbf{1}} \mathrm{MSC}$, and M S I mbabi ${ }^{\mathbf{2}} \mathrm{PhD}$}

\section{SUMMARY}

Dynamic insulation permits the movement of air and moisture through the external walls of a building to reduce heat loss and achieve high indoor air quality. The present paper details a pilot study carried out to examine the influence of fire safety requirements and external wind on the performance of naturally ventilated multi-storey buildings in which the external envelop is dynamically insulated. The theoretical foundation for a spreadsheet model, used to simulate prototype 3, 4, 5 and 10 storey buildings all sharing the same rectangular floor plan, with fresh air drawn into the building through the envelope by depressurisation using a fan-driven, ducted extract system, is outlined. From the analysis the effects of wall porosity, depressurisation level, extract system deployment, occupant density and distribution, and building orientation have been quantified, confirming the practical feasibility of such a system.

\footnotetext{
${ }^{1}$ Bruce J. Taylor is Research Associate, The Scott Sutherland School of Architecture, The Robert Gordon University, Aberdeen, AB10 7QB

${ }^{2}$ Mohammed S. Imbabi is Lecturer, The Department of Engineering, Kings College, The University of Aberdeen, Aberdeen, AB24 3UE
} 


\section{List of symbols}

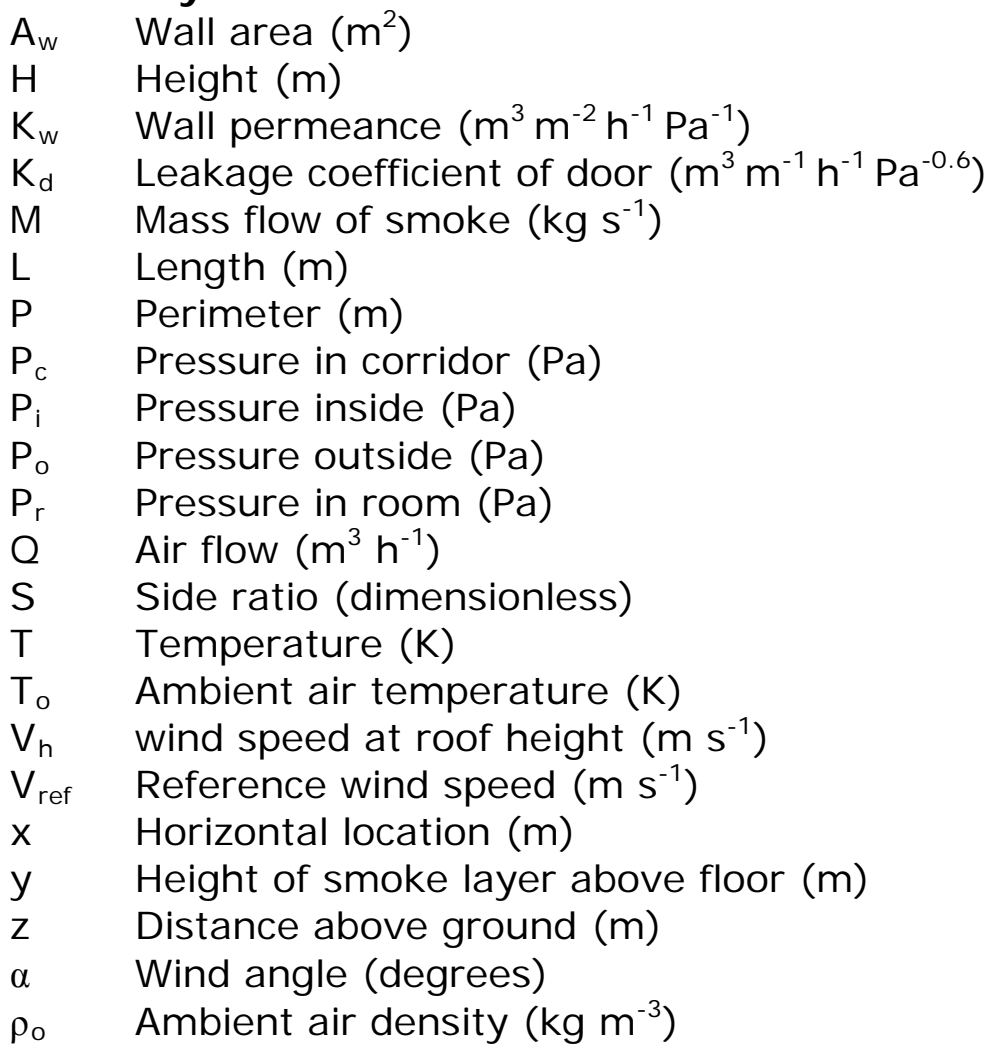

\section{Introduction}

Dynamic insulation is the generic term used to describe a class of construction materials that provide heat insulation and which are, in addition, permeable to the passage of gas and vapour. In buildings, dynamic insulation may be used to provide filtered and pre-warmed air for background ventilation with the benefit of reducing fabric heat losses during the heating season $[1,2]$.

The implementation of dynamic insulation in small buildings that can be treated as a single zone is relatively straightforward [3]. The practical consequences of installing dynamic insulation in more complex buildings, such as office blocks, shopping malls, museums, schools, etc... are not immediately obvious. This paper 
summarises the conclusions from a ventilation design analysis for a multi-storey building in which the walls are dynamically insulated. The starting points of the analysis are taken to be (a) the extreme conditions of fire and (b) the pressure variations on the external envelope caused by wind. Normally these are considered much later in the design process, but even in conventional airtight buildings they can have a profound effect on the design and should be considered earlier than they often are.

In the case of air permeable building envelopes the internal and external environments are intimately linked. The choice of air permeance of the walls thus has a direct bearing on the built environment. Taylor, Webster and Imbabi [4] have dealt with a single storey, single zone, and low occupancy buildings in which the problems of evacuating a building in the event of a fire are no more difficult than in a building with an airtight envelope.

However, smoke control in large multi-zone high occupancy buildings is a complex matter and it is important to address and quantify this issue when considering air permeable envelopes. The results presented clearly demonstrate that wind and smoke control strategies are key factors in determining the depressurisation level of the building and the air permeance of the wall.

\section{Building Description}

With reference to Figure 1, a simple cellular layout of rooms arranged off a central corridor that opens on to a stairwell is assumed. This is not untypical of many office buildings. A fire door leading to the stairwell at the end of the corridor defines this 
suite of rooms as a fire zone. The parameters assumed for the rooms are shown in Table 1.

The permeable wall areas are calculated from the dimensions in Figure 1. The building is assumed to have $50 \%$ glazing. Each door panel is assumed to be $2.0 \mathrm{~m} \times 0.9 \mathrm{~m}$. In calculating the influence of wind on ventilation, buildings of 3, 4, 5 and 10 storeys have been investigated. The floor to floor distance between the stories is taken to be $3.6 \mathrm{~m}$ and the internal floor to ceiling height is $3.0 \mathrm{~m}$. The gross plan area of the building is

$34.0 \mathrm{~m} \times 14.0 \mathrm{~m}$, or $476.0 \mathrm{~m}^{2}$.

\section{Ventilation Strategy}

Conventional ventilation ducting has two major drawbacks: ducts require cleaning to prevent them becoming an incubator and disseminator of micro-organisms, and they can have highpressure losses that result in fans with large power consumption. It should be possible in dynamically insulated buildings to eliminate extract ductwork by using the corridors and stairwells for venting air, provided it is not contaminated by smoke from fires or cigarettes, and toxic or unpleasant chemicals. I mplementation of such a strategy would be straightforward for a single storey building on a sheltered site where the effects of pressure variation over the envelope are small (i.e., of the order of $10 \mathrm{~Pa}$ or less). However, for a speculative multi-storey building it is shown later that the strategy results in an uneconomical loss of floor space. 
In our analysis of the use of air permeable envelopes in multi-storey buildings the following ventilation and fire safety strategy has been adopted. In putting forward this strategy the authors are not saying that other strategies are unacceptable or inferior but merely that the one proposed is reasonable within current practice. It will be shown that in order to ensure the minimum ventilation is achieved, each room needs be depressurised to approximately $-100 \mathrm{~Pa}$. The extract ducting arrangement required for this is shown in Figure 1 . In order to avoid problems with the opening of doors the corridor and stair well will also need to be depressurised to $-100 \mathrm{~Pa}$. These ducts feed ventilation shafts in the stairwell. This high level of depressurisation is required to overcome the pressure loss in the extract ducting and wind loading.

\section{FI RE SAFETY}

The Fire Authority, insurance companies, property developers, financiers and the building control authority require that measures be taken to ensure that escape routes are maintained free of smoke. Insurance companies and owners will also be concerned that financial loss be limited by containing the fire to within specified zones. In general, the issues that need to be addressed are [5]:

a) Would fire and smoke venting significantly assist in reducing the spread of fire and consequently losses pending the arrival of the Fire Brigade? 
b) Would the ready means of escape of persons within the building be assisted by smoke ventilation systems?

In the United Kingdom more specific guidance is found in Fire Precautions in the Design of Buildings, BS 5588 Part 3: Code of Practice for Office Buildings [6], and Part 9: Code of Practice for Ventilation and Air Conditioning Ductwork [7].

The first point to realise is that the rate of smoke generation even by a small fire is considerable. The mass flow of smoke, $M$, generated by flames at temperature $T(K)$ from a fire with perimeter $P(m)$ is found from [8]

$$
M=0.096 P \rho_{o} y^{3 / 2}\left(g \frac{T}{T_{o}}\right)^{1 / 2}
$$

Where $\rho_{0}$ and $T_{0}$ are the ambient air density and temperature respectively and $y$ is the height of the bottom of the smoke layer above the floor. The volume rate of production of smoke from a fire at a temperature of $1100 \mathrm{~K}$ in a waste paper bucket $(0.3 \mathrm{~m}$ diameter) in a room $3.0 \mathrm{~m}$ high is initially $10,000 \mathrm{~m}^{3} / \mathrm{h}$. For a tabletop fire the rate of production will easily be three times greater. As the smoke layer thickens Equation 1 shows that the rate of smoke production will decrease. When the room is half full of smoke the rate will have decreased by one third to $3000 \mathrm{~m}^{3} / \mathrm{h}$.

These rates are far in excess of anything that the ordinary extract vent system is designed to handle so its continued operation will succeed only in spreading the smoke to other parts of the building. The conclusion is that the extract vent system must be shut down in the event of a fire. In an airtight room the fire would soon extinguish itself. With air permeable walls, 
however, the fire will continue to be supplied with oxygen, so it is probable that fires will burn for longer in buildings with air permeable envelopes. This could be a desirable feature since it provides the opportunity for volatile vapours produced by pyrolysis of fuel in the room to be burned off in a controlled manner. This will reduce the risk of the fire suddenly flaring up again as soon as a fireman opens the door.

The designer must ensure that vent air movement is away from escape routes to prevent, as far as possible, smoke-laden air being carried into protected escape routes and exits. This means that if rooms are accessible only from one corridor then that corridor may not be used to vent air from rooms. However, occupants can be protected from smoke not only by physical barriers but also by distance. So in a building with very high ceilings the corridor could be used as a smoke reservoir provided the base of the reservoir is at least $1.5 \mathrm{~m}$ above the [8]. This, however, is an uneconomic solution because of the higher capital costs and reduced rental income from loss of floor space. Any method for smoke control that is proposed must meet the basic criteria that everybody must be able to get into a protected escape route within $2 \frac{1}{2}$ minutes.

The use of fire dampers in ventilation ducts allows the Fire Brigade to can choose whether to vent smoke or not. Another way of ensuring stairways remain free of smoke during a fire is to maintain the stairwell at positive pressure with respect to the rest of the building [9]. Reversing the ventilation fan direction and feeding the air only into the stairwell and corridors could be used to achieve this, provided the dampers isolating each room remain shut with no leakage. In order for the doors to be easily opened 
this positive pressure would be limited to $50 \mathrm{~Pa}$. To limit the leakage of air directly to the outside the stairwell and the corridors would have to be of an impermeable construction.

The air supplied to the corridors must pass easily out through the external walls so that the major pressure drop occurs across the room doors, to prevent leakage of smoke into the corridor around the top of a closed door. With a $15 \mathrm{~Pa}$ buoyancy pressure generated by the fire [10] a reasonable design objective would be to try and achieve a $45 \mathrm{~Pa}$ pressure drop across the door and the balance ( $5 \mathrm{~Pa}$ ) across the external wall. The pressure drop across the wall will depend on the permeance $\left(K_{w}\right)$ and area $\left(A_{w}\right)$ of wall, and the leakage coefficients $\left(K_{d}\right)$ and cumulative perimeter length (L) for the doors. In a room without a fire the flow of air around the door and through the wall is given by

$$
Q=K_{d} L\left(P_{c}-P_{r}\right)^{0.6}=K_{w} A_{w} P_{r}
$$

Where $\mathrm{P}_{c}$ and $\mathrm{P}_{\mathrm{r}}$ are the corridor and room pressures respectively. This can be re-arranged to

$$
\left(P_{c}-P_{r}\right)^{0.6}-\left(\frac{K_{w} A_{w}}{K_{d} L}\right) P_{r}=0
$$

Allowing for dimensional non-homogeneity, the above equation is easily solved for the room pressure by iteration. The room pressure clearly depends on the coefficient (units $\mathrm{Pa}^{-0.4}$ ) of $\mathrm{P}_{\mathrm{r}}$ in the above equation. Equation (3) has solutions for $\mathrm{P}_{\mathrm{r}}$ of under 5 and $10 \mathrm{~Pa}$ for raw values of $\mathrm{P}_{\mathrm{r}}$ of $2 \mathrm{~Pa}^{-0.4}$ and $1 \mathrm{~Pa}^{-0.4}$ respectively. This provides an easy method of calculating the required leak tightness of the door for any given door size, permeable wall area and wall permeance. For example, assume 
the corridor is pressurised at $50 \mathrm{~Pa}$, the perimeter of the door is $5.8 \mathrm{~m}$, the area of permeable wall is $10 \mathrm{~m}^{2}$ and the wall permeance is $0.1 \mathrm{~m}^{3} / \mathrm{m}^{2} \mathrm{hPa}$. In this case the leakage coefficient of the door needs to be less than $0.16 \mathrm{~m}^{3} / \mathrm{mhPa}^{0.6}$ to achieve a pressure drop of $10 \mathrm{~Pa}$ across the wall. If it is not practicable or economic to have doors with such good seals then vents could be fitted in the walls or the windows that permit the smoke to escape directly to atmosphere. These would have to open automatically in the event of a fire in the room.

Permeable internal walls would not provide acceptable fire barriers. The buoyancy pressures (15 Pa) generated by a fire in a sealed room would force hot, toxic gas through into adjacent rooms at ceiling level, increasing the ease with which fire will propagate. Although a permeable wall would filter out the relatively large particles ( $\sim 10 \mu \mathrm{m}$ diameter) which are characteristic of smoke [1], the invisible toxic gases may still overpower occupants in adjacent rooms.

In the De Montfort University School of Engineering in Leicester, individual spaces that were naturally ventilated had to be given individual stacks because the Local Fire Authority required separate venting of each area. Fortunately, experimental and theoretical modelling showed that this was also desirable to prevent stale air from spreading into adjacent areas. This gives rise to De Montfort's characteristic and attractive chimneys. On a fire alarm, the air intakes for the naturally ventilated areas shut and exhausts open automatically. Also, manual switches allow fire officers to close exhausts if they decide to starve the fire of oxygen. Based on this experience it may be that air permeable external walls would need a means of 
excluding external air. To do this in a practical way means bring the air into the wall at a limited number of points rather than over the whole external surface. This would considerably increase the pressure drop of the air supply system, adding to cost and complexity.

\section{Air-permeable walls}

Although ducted ventilation systems have their problems, as mentioned above, a ducted extract system is the only feasible option in a dynamically insulated multi-storey building. To recap, multi-storey buildings need to be depressurised to -100 Pa or higher in order to ensure that air flows inwards through the wall at all points in the envelope for adequate ventilation to be provided in every room. The absolute value of the depressurisation will increase as the building height and ambient wind speed increases. This level of depressurisation requires a ducted system, since using corridors would make airflows and pressures difficult to control as people use the building.

The choice of air permeance for the walls is confined to a narrow range. From Appendix 1 it can be seen that the materials which could potentially be used in a permeable wall will result in an overall wall permeance of between $0.1 \mathrm{~m}^{3} / \mathrm{m}^{2} \mathrm{hPa}$ and 1 $\mathrm{m}^{3} / \mathrm{m}^{2} \mathrm{hPa}$. Plasterboard will be an effective air barrier whereas other materials, such as insulation or wood wool panels with permeance greater than $1 \mathrm{~m}^{3} / \mathrm{m}^{2} \mathrm{hPa}$, can not be used on their own. For simplicity and economy of construction the permeance of the envelope needs to be uniform. In our building model the permeance has not been varied to compensate for variations in 
the pressure drop across the envelope in order to provide a more uniform distribution of air. Instead, advantage will be taken of the variations around the building of the airflow through the envelope to allocate appropriate uses for the internal compartments. Activities that require high ventilation rates because of high occupancy density, high heat or pollution loads were thus located on the windward side of the building.

\section{Wind effects}

To quantify the effects of wind speed, building height and the air permeance of the walls on the depressurisation and the occupancy pattern within the building, the pressure coefficients around a tall building were calculated using the Swami and Chandra [11] correlation for high rise buildings.

$$
\begin{aligned}
C_{p}= & 0.068-0.01464 \alpha+1.733 \cos (2 \alpha)-1.556 Z_{H} S^{0.169} \sin (\alpha)-0.922 S^{0.279} \cos (2 \alpha) \\
& +0.344 \sin (2 \alpha)-0.801 Z_{H} \cos (\alpha)+1.118 \cos \left(X_{r}\right)-0.961 \cos \left(X_{r} \alpha\right) \\
& +0.691 S^{0.245} \cos \left(X_{r} \alpha\right)+2.515 Z_{H} \sin (\alpha)+0.399 X_{r} \sin (\alpha) \\
& -0.431 X_{L}+0.046 S^{0.85} \cos \left(X_{r}\right)
\end{aligned}
$$

(4)

Where

$$
\begin{aligned}
& X_{r}=2\left(X_{L}-0.5\right), \\
& X_{L}=\frac{X}{L}
\end{aligned}
$$




$$
\begin{aligned}
& Z_{H}=\frac{Z}{H}, \\
& \alpha=\text { wind angle (in degrees) between the wind direction and } \\
& \text { the outward normal to the wall, } \\
& \mathrm{S}=\text { side ratio, i.e. the ratio of the width of the wall under } \\
& \text { consideration to the width of the adjacent wall, } \\
& x=\text { the horizontal location of a point from the edge of the } \\
& \text { wall, } \\
& z=\text { distance above ground of point on the wall, } \\
& \mathrm{L}=\text { length of wall under consideration, } \\
& \mathrm{H}=\text { height of building. }
\end{aligned}
$$

The pressure coefficient was calculated at the midpoint of each external wall for every room. The external pressure $P_{0}$ at that point is readily calculated from the wind speed at roof height V using

$$
P_{o}=C_{p}\left(\frac{1}{2} \rho V^{2}\right)
$$

The wind speed at roof height is estimated from standard expressions [12] for estimating wind speed as function of height and local terrain, which in this case is assumed to be urban and the wind speed at the reference site, $V_{\text {ref, }}$ is measured in flat open country.

$$
V=\frac{1}{0.67}\left(\frac{z}{10}\right)^{0.25} V_{\text {ref }}
$$


The airflow through the wall varies in direct proportion to the pressure difference across the wall

$$
Q=K A\left(P_{o}-P_{i}\right)
$$

The internal pressure $P_{i}$ is arranged to be the same in every room.

A minimum ventilation rate of $8 \mathrm{l} / \mathrm{s} /$ person is assumed. This is the CIBSE recommendation assuming no smoking by occupants. Therefore as the airflow varies over the envelope, the windward side of the building will have a greater supply of fresh air than on the leeward and so one can arrange the highest occupation densities on that side of the building. Single occupation offices can be located on the leeward side of the building. This is a feasible arrangement where the building location has a very pronounced prevailing wind direction. This is the basis of the spreadsheet model used to explore the implications of dynamic insulation for the design of multi-storey offices.

The pressure at the centre of an external wall panel is taken to be representative of the external pressure for that room and hence gives an estimate of the airflow into the room through the wall. The maximum number of occupants for that location is simply the airflow rate through the wall divided by ventilation rate per person. The maximum number of occupants for each location is summed to give the total number of occupants for the whole building. The results of such calculations are shown in Tables 2 and 3 for wind speeds of $10 \mathrm{~m} / \mathrm{s}$ and $5.5 \mathrm{~m} / \mathrm{s}$ respectively. 
For any given wall permeance increasing the building height increases the depressurisation required to maintain the minimum ventilation rate but as rooms on the windward side will be increasingly ventilated so the potential occupancy increases. Buildings with a low air permeance will require larger absolute depressurisations and have lower occupancies than more permeable envelopes. Table 2 indicates that dynamically insulated buildings in excess of 10 storeys are not likely to be a practical proposition because of the very excessive depressurisation required.

The pattern of occupancy predicted by these calculations is summarised in Table 4. This shows the number of occupants in each room of a 10-storey building with a wall permeance of 0.1 $\mathrm{m}^{3} / \mathrm{m}^{2} \mathrm{hPa}$ in a wind speed of $5.5 \mathrm{~m} / \mathrm{s}$, except for room 2 on the 9 th and 10th floors, which can only have 4 occupants. This gives a total of 188 occupants as shown in Table 3. The average space allocation is $18 \mathrm{~m}^{2}$ per occupant, which is generous by office standards. The extravagant space allocation of $72 \mathrm{~m}^{2}$ per occupant for the largest rooms could not be economically justified.

If the design wind speed is $5.5 \mathrm{~m} / \mathrm{s}$ (the wind speed at Aberdeen which is likely to be exceeded $50 \%$ of the time) then it is necessary to calculate what the required depressurisation would be at a higher wind speed (say $10 \mathrm{~m} / \mathrm{s}$ ) for surplus capacity. It is also necessary to derive the ventilation per occupant supplied to each room in a similar manner. For a 10 storey building with a wall permeance of $0.1 \mathrm{~m}^{3} / \mathrm{m}^{2} \mathrm{hPa}$ the depressurisation required at a wind speed of $10 \mathrm{~m} / \mathrm{s}$ to ensure the minimum ventilation per person is $-121 \mathrm{~Pa}$. The maximum ventilation rate per person 
increases from $14.9 \mathrm{l} / \mathrm{s} /$ person to $30.9 \mathrm{l} / \mathrm{s} /$ person. The average air change rate for the whole building increases from 0.39 ach to 0.62 ach. Even for a modest 4 storey building the depressurisation required for the same conditions is $-95 \mathrm{~Pa}$. A lesser depressurisation could in theory be achieved by employing an external wall of permeance $1 \mathrm{~m}^{3} / \mathrm{m}^{2} \mathrm{hPa}$. Such a wall would in effect be just insulation, without any physical protection. This points to the need for a masonry block with the permeance of insulation.

The depressurisation that can be practically achieved depends on the design of the extract ventilation system. For the case considered and assuming a duct airspeed of $1.5 \mathrm{~m} / \mathrm{s}$ the duct sizes on each floor would be $0.4 \mathrm{~m}$ and $0.3 \mathrm{~m}$ diameter on the windward and leeward sides respectively. Assuming a single extract fan then the duct supplying this fan would be the equivalent of $1.6 \mathrm{~m}$ diameter. The duct pressure losses are all less than $0.08 \mathrm{~Pa} / \mathrm{m}$. This gives plenty of scope to design, possibly with higher air speeds, an extract ventilation system that can achieve depressurisations over the range -50 to $-100 \mathrm{~Pa}$.

The investigation thus far highlights a number of design issues when designing a dynamically insulated multi-storey building:

1. With very large depressurisation the rest of the envelope needs to be exceptionally air and watertight. At such pressures water drawn by capillary forces into minute pores or gaps in the envelope will be blown through to the inside. Considerable amounts of water can enter a building by this mechanism. 
2. The occupancy and processes occurring in each room have to be allocated according to the ventilation that will be supplied through the wall.

3. The ventilation provided through the wall is only an exact match to the ventilation required in a room at the design wind speed and direction. At other conditions the majority of rooms will be over-ventilated.

4. The depressurisation within each room needs to vary with wind speed and direction. This is relatively easy to achieve when the building is small and encloses a single open space. In compartmentalised buildings it will require the dampers in the extract ducts to be controlled by a transducer measuring the differential pressure across the external wall(s) of the room.

There are ways of side-stepping these issues. For example, by enclosing the building within a wind barrier with sufficient gap around it and the building proper the small pressure differences that occur over the envelope quickly equalise and rain penetrating the barrier will not cross over to the permeable envelope. Alternatively channels might be provided through the building, say in the floor, to equalise the pressures on windward and leeward sides of the building.

\section{Discussion}


From considerations of fire safety it has been concluded that a ducted extract ventilation system would be more appropriate for most building types rather than using the corridors for ventilation. In the event of a fire the damper in the ventilation extract from each room should automatically shut. Whilst the ventilation extract plays no part in smoke control, the extract grille in a room cannot be placed in the optimum position for ventilation, which is opposite the external wall, since one must consider the implications for human safety of a damper failing to shut. Therefore, a compromise position for the extract grille would be in the centre of the room. Air permeable internal walls are unsafe because they will not prevent the spread of hot, toxic gases during a fire.

For simplicity of construction the permeance of the external wall should be the same over the whole envelope and in the range 0.1 to $1.0 \mathrm{~m}^{3} / \mathrm{m}^{2} \mathrm{hPa}$. Windows must not be capable of being opened. Whilst this is an essential feature for the reliable operation of dynamic insulation it is also desirable in many buildings where physical security of the building and its contents are important. For example, in a library, openable windows and vents provide a means of uncontrolled access and a route for passing out books. Individual control of the ventilation in a room may be provided by enabling manual override of the control system of the extract duct damper from each room. The external door needs also to be reasonably leak-tight, so short of using an airlock a revolving door is probably the only practical solution.

There are a number of important benefits in using dynamic insulation. In an urban environment, in summer, suffering greatly from noise and chemical pollution occupants often keep windows 
closed, despite the need for ventilation, in order to be able hear colleagues or to concentrate on their work or to keep dust and dirt off their paperwork and sensitive office equipment. Theory suggests that air permeable walls have the potential to filter particulate pollution and reduce outdoor [1]. Dynamic insulation also provides outside air without draughts. This is useful in winter but its efficacy in providing a fresh atmosphere in summer remains to be established. This is because dynamic insulation removes two characteristics which contribute to a fresh environment, namely air movement and turbulence intensity, and it remains to be established that dynamic insulation makes a room fresher just by virtue of higher air change rate alone.

The building form considered here has been narrow and an open window could just as easily ventilate the rooms. Cross ventilation can aerate a building up to $15 \mathrm{~m}$ deep. In a deep plan building using dynamic insulation, air will need to be cascaded from rooms at the periphery to those at the centre by ducting. This will require rooms at the periphery to be pollution free and with low occupation density. An alternative arrangement that overcomes these restrictions is to use a porous ceiling with air being distributed through floor/ceiling voids.

The ventilation systems described above are $100 \%$ fresh air systems. There is no opportunity to recycle a proportion of the warm air around the building in order to

a. reduce ventilation heat loss, and

b. remove internally generated particulates from the air. 
These desirable features could be incorporated if some of the warm air were fed into the outer building cavity. This would not be as efficient as a ducted re-circulation system because the warm air would lose heat to the outside via the uninsulated cladding.

Finally, the Swami and Chandra [11] correlation for high rise buildings should only be used in the initial stage of the design in order to generate the broad parameters for the building and its use. This is because it is not an exact correlation and there can be considerable variation between the predicted value of the pressure coefficient and the actual value. Therefore, measurements of the pressure coefficients around the proposed building must be conducted by carrying out wind tunnel tests on a scale model that includes an accurate representation of the terrain and surroundings.

\section{Conclusions}

The findings presented show how dynamic insulation could be applied in a cellular multi-storey office block and also highlight the design considerations of fire safety and wind loading. It is conceded that a dynamically insulated office may have certain limitations compared with a conventional mechanical supply and extract system. The building height is limited by the depressurisation to around $36 \mathrm{~m}$ (10 storeys), depending on the local climate and topography. The location of occupants and work processes is also determined by these external factors, which will limit options on change of use for the building. The building performance could be adversely affected by developments on 
adjacent sites over which the building user and owner may have little or no control. However, there are a number of advantages. In city centre environments chemical pollution and noise from motor vehicles and other sources require buildings to be sealed and air to be supplied and filtered by mechanical systems. Air permeable walls can fulfil both these requirements with less plant and lower energy requirements, thereby reducing the initial and running costs of the building. 


\section{APPENDIX 1}

Measured Air Permeability of Building Materials [13].

\begin{tabular}{|c|c|c|c|c|}
\hline Material & $\begin{array}{c}\text { Permeability } \\
\left(\mathrm{m}^{2} / \mathrm{hPa}\right)\end{array}$ & $\begin{array}{c}\text { Thickness of } \\
\text { Layer }(\mathrm{mm})\end{array}$ & $\begin{array}{c}\text { Permeance } \\
\left(\mathrm{m}^{3} / \mathrm{m}^{2} \mathrm{hPa}\right)\end{array}$ & $\begin{array}{c}\text { Pressure Drop } \\
(\mathrm{Pa}){ }^{1}\end{array}$ \\
\hline Plasterboard & $1.06 \times 10^{-5}$ & 12 & $8.81 \times 10^{-4}$ & 1140 \\
$\begin{array}{c}\text { Thermal block } \\
\text { (density 850 kg/m3) }\end{array}$ & $1.6 \times 10^{-5}$ & 100 & $1.9 \times 10^{-4}$ & 526 \\
\hline Fibreboard & $1.34 \times 10^{-3}$ & 12 & $1.16 \times 10^{-1}$ & 8.6 \\
\hline $\begin{array}{c}\text { Pumalite } \\
\text { (density 870 kg/m3) }\end{array}$ & $3.6 \times 10^{-2}$ & 100 & $3.6 \times 10^{-1}$ & 2.8 \\
\hline $\begin{array}{c}\text { Cellulose / wet blown } \\
\text { (density 47 kg/m3) }\end{array}$ & 0.283 & 200 & 1.50 & 0.67 \\
\hline $\begin{array}{c}\text { Cellulose / dry blown } \\
\text { (density 65 kg/m3) }\end{array}$ & 0.25 & 150 & 1.67 & 0.60 \\
\hline $\begin{array}{c}\text { Sheep's wool } \\
\text { (density 28kg/m3) }\end{array}$ & 1.8 & 140 & 13.0 & 0.08 \\
\hline
\end{tabular}


Measured Air Permeability of Building Materials [2]

\begin{tabular}{|c|c|c|c|c|}
\hline Material & $\begin{array}{l}\text { Density } \\
(\mathrm{kg} / \mathrm{m} 3)\end{array}$ & $\begin{array}{l}\text { Thickness of } \\
\text { Layer }(\mathrm{mm})\end{array}$ & $\begin{array}{l}\text { Permeance } \\
\left(\mathrm{m}^{3} / \mathrm{m}^{2} \mathrm{hPa}\right)\end{array}$ & $\begin{array}{c}\text { Pressure Drop } \\
(\mathrm{Pa})^{1}\end{array}$ \\
\hline \multirow[t]{5}{*}{ Glasswool } & 115 & 100 & 1.0 & 1.0 \\
\hline & 60 & 100 & 1.44 & 0.7 \\
\hline & 36 & 100 & 1.8 & 0.56 \\
\hline & 16 & 100 & 5.5 & 0.18 \\
\hline & 16 & 50 & 11.0 & 0.091 \\
\hline \multirow[t]{5}{*}{ rock wool } & 160 & 100 & 0.42 & 2.4 \\
\hline & 120 & 50 & 1.64 & 0.61 \\
\hline & 80 & 80 & 1.5 & 0.67 \\
\hline & 50 & 100 & 2.06 & 0.49 \\
\hline & 30 & 50 & 7.34 & 0.14 \\
\hline perlite & 125 & 75 & 1.11 & 0.90 \\
\hline $\begin{array}{l}\text { Wood wool panels } \\
\text { (fine structure) }\end{array}$ & 480 & 35 & 45 & 0.022 \\
\hline $\begin{array}{l}\text { Wood wool panels } \\
\text { (rough structure) }\end{array}$ & 460 & 35 & 350 & 0.0029 \\
\hline $\begin{array}{l}\text { Wood wool panels } \\
\text { (rough structure) }\end{array}$ & 460 & 50 & 240 & 0.0042 \\
\hline
\end{tabular}

(1) Pressure drop calculated at flow rate of $1 \mathrm{~m}^{3} / \mathrm{m}^{2} \mathrm{~h}$ 


\section{Acknowledgements}

This work has been funded by the Engineering and Physical Sciences Research Council (EPSRC), Grant Reference GR/K23461. 


\section{References}

1. Taylor B J, Webster R and Imbabi M S, The building envelope as a filter of Urban Air Pollution, Building and Environment, 1998, 34, pp 353-361

2. Bartussek H, Natural ventilation by thermal buoyancy and by outside convections: practical application of natural ventilation systems with chimneys and breathing ceilings. Dublin: Proceedings of the 11th International Congress on Agricultural Engineering, 251-267 (1989).

3. Taylor B J and Imbabi M S, Environmental design using dynamic insulation, ASHRAE Transactions, 106, Part 1, 2000.

4. Taylor B J and Imbabi, M S, The application of dynamic insulation in buildings, Renewable Energy, 15, 377-382 (1998).

5. CIBSE, Installation and equipment data-Volume B, London: CIBSE (1986).

6. BSI, Fire precautions in the design of buildings_-BS 5588 part 3:

Code of practice for office buildings, London: BSI (1983). 
7. BSI, Fire precautions in the design of buildings - BS 5588 Part 9: Code of practice for ventilation and air conditioning ductwork, London: BSI (1989).

8. Butcher E G and Parnell A C, Smoke control in fire safety design, London: E\&F N Spon (1979).

9. BSI, Fire precautions in the design of buildings — BS 5588 Part 4: Smoke control in protected escape routes using pressurisation, London: BSI (1978).

10. Zickerman J (ed.), Fire safety in tall buildings, Council on Tall Buildings \& Urban Habitat-Committee 8A, New York: McGrawHill (1992).

11. Swami M V and Chandra S, Correlations for pressure distribution on buildings and calculation of natural-ventilation airflow, ASHRAE Transactions, 94(1), 243-266 (1988).

12. Awbi H B, Ventilation of Buildings, London: E \& F N Spon (1991).

13. Taylor B J, Cawthorne D A and Imbabi M S, Analytical investigation of the steady-state behaviour of dynamic and diffusive envelopes, Building \& Environment, 31(6), 519-525 (1996). 
TABLE 1.

Building parameters used in the analysis.

\begin{tabular}{|c|c|c|c|}
\hline Room & Floor Area $\left(\mathrm{m}^{2}\right)$ & $\begin{array}{c}\text { Permeable Wall } \\
\text { Area }\left(\mathrm{m}^{2}\right)\end{array}$ & $\begin{array}{c}\text { Crack length } \\
\text { around Doors (m) }\end{array}$ \\
\hline 1 & 48.0 & 36.0 & 5.8 \\
\hline 2 & 48.0 & 36.0 & 5.8 \\
\hline 3 & 72.0 & 21.6 & 9.6 \\
\hline 4 & 72.0 & 21.6 & 9.6 \\
\hline 5 & 24.0 & 7.2 & 5.8 \\
\hline 6 & 24.0 & 7.2 & 5.8 \\
\hline 7 & 24.0 & 7.2 & 5.8 \\
\hline 8 & 24.0 & 7.2 & 5.8 \\
\hline Total & 336.0 & 144.0 & 54.0 \\
\hline
\end{tabular}




\section{TABLE 2.}

Occupant densities and depressurisations for a wind speed of $10 \mathrm{~m} / \mathrm{s}$.

\begin{tabular}{|c|c|c|c|}
\hline $\begin{array}{l}\text { Building } \\
\text { height (m) }\end{array}$ & $\begin{array}{l}\text { Permeance } \\
\left(\mathrm{m}^{3} / \mathrm{m}^{2} \mathrm{hPa}\right)\end{array}$ & $\begin{array}{l}\text { Maximum No } \\
\text { of occupants }\end{array}$ & $\begin{array}{c}\text { Depressurisation } \\
\qquad(\mathrm{Pa})\end{array}$ \\
\hline \multirow{2}{*}{$\begin{array}{c}36.0 \\
\text { (10 storeys) }\end{array}$} & 1.0 & 2862 & -98.7 \\
\hline & 0.1 & 332 & -121.3 \\
\hline \multirow{2}{*}{$\begin{array}{c}18.0 \\
\text { (5 storeys) }\end{array}$} & 1.0 & 1030 & -66.2 \\
\hline & 0.1 & 142 & -99.3 \\
\hline \multirow{2}{*}{$\begin{array}{c}14.4 \\
\text { (4 storeys) }\end{array}$} & 1.0 & 722 & -57.5 \\
\hline & 0.1 & 110 & -95.0 \\
\hline \multirow{2}{*}{$\begin{array}{c}10.8 \\
\text { (3 storeys) }\end{array}$} & 1.0 & 454 & -47.5 \\
\hline & 0.1 & 82 & -90.0 \\
\hline
\end{tabular}


TABLE 3.

Occupant densities and depressurisations for a wind speed of $5.5 \mathrm{~m} / \mathrm{s}$.

\begin{tabular}{|c|c|c|c|}
\hline $\begin{array}{l}\text { Building } \\
\text { height (m) }\end{array}$ & $\begin{array}{l}\text { Permeance } \\
\left(\mathrm{m}^{3} / \mathrm{m}^{2} \mathrm{hPa}\right)\end{array}$ & $\begin{array}{l}\text { Maximum No } \\
\text { of occupants }\end{array}$ & $\begin{array}{l}\text { Depressurisation } \\
\text { (Pa) }\end{array}$ \\
\hline \multirow{2}{*}{$\begin{array}{c}36.0 \\
\text { (10 storeys) }\end{array}$} & 1.0 & 842 & -29.9 \\
\hline & 0.1 & 188 & -70.1 \\
\hline \multirow{2}{*}{$\begin{array}{c}18.0 \\
\text { (5 storeys) }\end{array}$} & 1.0 & 296 & -20.0 \\
\hline & 0.1 & 89 & -60.4 \\
\hline \multirow{2}{*}{$\begin{array}{c}14.4 \\
\text { (4 storeys) }\end{array}$} & 1.0 & 206 & -17.4 \\
\hline & 0.1 & 64 & -57.5 \\
\hline \multirow{2}{*}{$\begin{array}{c}10.8 \\
\text { (3 storeys) }\end{array}$} & 1.0 & 128 & -14.4 \\
\hline & 0.1 & 33 & -43.4 \\
\hline
\end{tabular}


TABLE 4.

Pattern of occupancy in 10-storey building

\begin{tabular}{|l|c|c|c|c|c|c|c|c|}
\hline Room & 1 & 2 & 3 & 4 & 5 & 6 & 7 & 8 \\
\hline No of occupants & 4 & 5 & 1 & 1 & 3 & 3 & 1 & 1 \\
\hline $\mathrm{m}^{2}$ /occupant & 12 & 10 & 72 & 72 & 8 & 8 & 24 & 24 \\
\hline
\end{tabular}




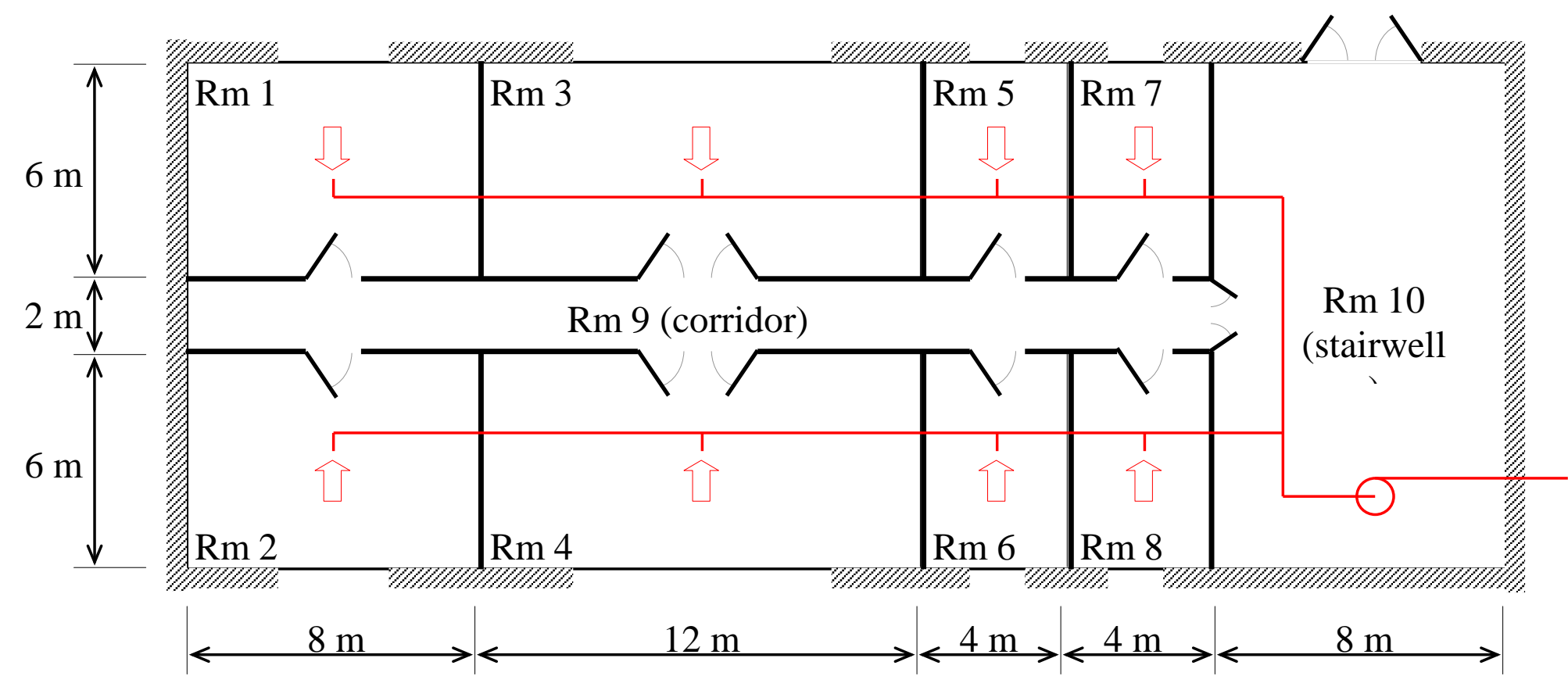

Figure 1: Floor plan of the building. 